THE AFFECTIVE TURN 



\section{The Affective Turn}

\section{THEORIZING THE SOCIAL}

Edited by PATRICIA TICINETO CLOUGH,

with JEAN HALLEY

FOREWORD BY MICHAEL HARDT

Duke University Press

Durham and London

2007 
(C) 2007 DUKE UNIVERSITY PRESS

ALL RIGHTS RESERVED

PRINTED IN THE UNITED STATES OF

AMERICA ON ACID-FREE PAPER $\infty$

DESIGNED BY AMY RUTH BUCHANAN

TYPESET IN MINION BY KEYSTONE

TYPESETTING, INC.

LIBRARY OF CONGRESS CATALOGING-

IN-PUBLICATION DATA APPEAR ON THE

LAST PRINTED PAGE OF THIS BOOK. 